УДК 343.6

Волошина Ю.В. ${ }^{\odot}$

аспірант

(Дніпропетровський державний університет внутрішніх справ)

DOI: $10.31733 / 2078-3566-2018-1-146-150$

\title{
ТЕОРЕТИЧНИЙ АНАЛІЗ СПЕЦІАЛЬНО-КРИМІНАЛЬНОГО ЗАПОБІГАННЯ ПОГРОЗАМ ЗАСТОСУВАННЯ ФІЗИЧНОГО НАСИЛЬСТВА
}

Проаналізовано сутність кримінально-спеціального запобігання погрозам застосування фізичного насильства, здійснено спробу з'ясування сутності та дослідження понять «запобігання злочинам», «погроза застосування фізичного насильства», «спеціально-кримінальне запобігання», «кримінологічна профілактика», «відвернення злочинів», «припинення злочинів».

Ключові слова: запобігання, фізичне насильство, погроза, кримінально-спеціальне запобігання, сочіум, насильницькі злочини, кримінологічна профілактика, відвернення злочинів, припинення злочинів.

Актуальність дослідження полягає у необхідності підвищення рівня забезпеченості прав і свобод людини та громадянина, оскільки вони є об'єктивним критерієм демократичності та цивілізованості будь-якої держави.

Фізичне насильство та погрози його застосування під час вчинення злочинів $є$ одним 3 найнебезпечніших антисоціальних та криміногенних факторів, що можуть поставити під загрозу життя однієї чи багатьох людей, саме тому ефективні спеціальнокримінальні заходи запобігання погрозам застосування фізичного насильства повинні завжди мати місце в національному законодавстві.

Рівень запобігання погрозам застосування фізичного насильства у спеціальнокримінальний спосіб слугує індикатором затвердження принципів правової державності та розвитку й утвердження в конкретній державі ідеалів демократії загалом.

Спираючись на такий підхід, зазначимо, що особливої гостроти та актуальності набуває питання індивідуальної безпеки громадян, що населяють нашу країну, яке у свою чергу залежить від місця проживання (населеного пункту), в межах якого виникають соціальні зв'язки між різними особами.

Ряд вчених та мислителів досліджували вказану тематику, доходячи певних висновків і наводячи аргументацію, це зокрема: А.В. Варданян, В.В. Голіна, В.В. Лунєєв, В.І. Сімонов, В.М. Кудрявцев, В.О. Василевич, Е.П. Побігайло, І.Н. Даньшин, Л.В. Сердюк, Л.Д. Гаухман, М.І. Панов, Н.К. Котова, Н.Х. Сафіуллін, О.С. Михайлов, О.М. Костенко, Р.О. Базаров, Р.О. Левертова, С.М. Абельцев, Ю.М. Антонян та багато інших, але, незважаючи на таке широке поле осмислення, дана тематика в сучасній Україні все ще $\epsilon$ актуальною.

Метою статті є дослідження спеціально-кримінального запобігання погроз застосування фізичного насильства. Постановка мети, в свою чергу, дозволяє окреслити перелік завдань, до яких відносяться: загальнотеоретичний аналіз підходів до розуміння понять «запобігання злочинності», «кримінально-спеціальне запобігання злочинам», «погроза застосування фізичного насильства» та окреслення їх змісту.

Виклад основного матеріалу. Про те, що краще запобігти злочину, ніж карати за його вчинення, писали і засновник теорії кримінального права Ч. Беккаріа, і великий мислитель XVIII ст. Ф.-М. Вольтер, і багато інших видатних вчених [1].

До того ж, існує ще більша кількість тих вчених, хто досліджував поняття «запобігання злочинності» та дійшов до різних його інтерпретацій. Але в будь-якому разі така концепція зайвий раз доводить, що попередження та протидія злочинності є більш ефективним засобом забезпечення прав і свобод людини та громадянина, аніж розслідування та розкриття вже вчинених злочинів.

У свою чергу, на думку Є. Бафія, запобіганням злочинності є «вчення про систему заходів (програму), які з урахуванням даних інших наук i, зокрема, інших розділів кри-

(C) Волошина Ю.В., 2018 
мінології слід впровадити в життя, щоб обмежити соціальне явище злочинності» [2].

На думку А.Ф. Зелінського, запобігання злочинності - це система заходів, яких вживає суспільство, щоб стримувати зростання злочинності i, по можливості, знизити їі реальний рівень шляхом усунення та нейтралізації ії причин та умов, що їй сприяють (профілактики), а також через запобігання та припинення окремих конкретних злочинів [3].

Таким чином, слід додатково аргументувати наступне: поняття профілактики злочинів сьогодні трактується по-різному, але, так чи інакше, всі дослідники розуміють під ним одне - систему цілеспрямованих заходів з протидії, зменшення та можливого подолання злочинності.

У свою чергу, запобігання злочинності поділяється на різновиди, серед яких i спеціально-кримінальне запобігання злочинності.

Спеціально-кримінальна протидія злочинності - це сукупність кримінальноправових, кримінально-процесуальних, оперативно-розшукових, криміналістичних та кримінологічних засобів, які забезпечують безпосередній правовий та кримінологічний вплив на реальні й потенційні злочинні прояви. Суб'єктами такої протидії є не всі соціальні та державно-правові інституції і навіть не всі правоохоронні органи, а лише спеціально уповноважена їх частина, що отримала назву «кримінальна юстиція». У найбільш загальному виді кримінальна юстиція - це система державних органів, діяльність яких спрямована на винесення справедливого рішення у кримінальній справі [4].

Також деякі автори називають цей різновид протидії злочинності «спеціальнокримінологічним запобіганням» та вважають, що це сукупність заходів боротьби зі злочинністю, змістом яких є різноманітна робота державних органів, громадських організацій, соціальних груп і громадян, спрямована на усунення причин та умов, що породжують злочинність і сприяють їй, а також недопущення вчинення злочинів на різних стадіях злочинної поведінки. Спеціально-кримінологічне запобігання злочинам складається із трьох напрямів діяльності: кримінологічної профілактики; відвернення злочинів; припинення злочинів [5].

Узагальнюючи підходи до розуміння вказаного поняття, зазначимо, що спеціально-кримінальними (кримінологічними) заходами є така діяльність ряду спеціально уповноважених державних органів та громадських організацій, що спрямована на забезпечення безпосереднього правового та кримінологічного впливу на реальні й потенційні злочинні прояви.

Окрім цього, відомі вчені та практики розрізняють кримінально-спеціальне запобігання вчиненню погроз застосування фізичного насильства за напрямками, а саме: кримінологічна профілактика, відвернення злочинів; припинення злочинних проявів.

Кримінологічна профілактика - це сукупність заходів щодо завчасного виявлення та усунення негативних явищ, які виникли чи можуть виникнути і детермінувати злочинність або їі окремі види [6].

Кримінологічна профілактика в контексті можливого вчинення погроз застосування фізичного насильства носить досить важливий характер, оскільки після проведення роз'яснювальної роботи щодо нетерпимості вчинення таких дій, тренінгів та лекцій на тематику взаємоповаги та доброти від працівників органів охорони правопорядку чи громадських організацій або об'єднань громадян велика кількість осіб, які могли припустити вчинення ними таких дій, мають підстави та аргументи, надані їм, щоб відмовитись від подібних злочинних намірів.

Відвернення злочинів - це специфічний напрям спеціально-кримінологічного запобігання, що складається із сукупності заходів, спрямованих на окремі групи та конкретних осіб, які виношують злочинні наміри, замислюють вчинення злочинів і позитивно сприймають злочинний спосіб життя, з метою дискредитування злочинної поведінки, добровільної відмови від злочинної мотивації та наміру або продовження злочинної діяльності [6].

Разом із тим Ю.Ф. Іванов та О.М. Джужа стверджують, що припинення є системою заходів, які застосовуються на стадії замаху на вчинення злочину з метою відвернення злочинного результату [7].

Відвернення відрізняється від профілактики тим, що профілактика здійснюється стосовно певної публіки незалежно від того, замислив хтось 3 присутніх злочин чи ні, а відвернення та всі дії, що здійснюються щодо осіб, які цілеспрямовано рухаються до вчинення злочину, реалізується для сприяння відмові від замислених злочинних намірів, 
до початку їх вчинення.

Припинення злочинних проявів визначається як сукупність видів діяльності, спрямованих на недопущення завершення розпочатого злочину шляхом розроблення $\mathrm{i}$ здійснення спеціальних заходів. Особливість запобіжної роботи на стадіях готування і замаху на злочин залежить від обсягу виконаної злочинної діяльності, особи винного, характеру злочину тощо [8].

Тобто припинення полягає в здійсненні спеціальних заходів, що мають на меті припинити вчинення вже розпочатого злочину до його закінчення.

Звертаючись до загальних статистичних даних, в Україні в період із січня по червень, спираючись на дані прес-служби Державної служби статистики, протягом 2017 року було скоєно 317633 злочини [9].

Із загальної кількості зафіксованих правоохоронними органами кримінальних проявів виділяють такі види: 36\% - тяжкі та особливо тяжкі (зазначається, що за перше півріччя відбулося 834 умисних вбивства і замахи на вбивство, а також 1050 умисних тяжких тілесних ушкоджень, 144 згвалтування і замахи на згвалтування).

Крім того, зафіксовано понад 160 тисяч крадіжок, 25,6 тис. випадків шахрайства, а також по 1,6 тис. розбоїв і хабарництва.

Кількість потерпілих від злочинів у січні-червні 2017 року становила 223,7 тис. осіб, серед яких 80,9 тис. - жінки, 13,4 тис. - особи похилого віку та з інвалідністю 1 і 2 груп, 2,6 тис. - неповнолітні та 1,2 тис. - діти до 14 років.

Таким чином, логічно припустити, що певний відсоток від загальної кількості злочинів відображає злочини, що були вчинені із застосуванням погроз фізичного насильства.

Виходячи із цього, належить додатково дослідити поняття «погроза застосування фізичного насильства», що може бути наведено в нормативно-правових актах або наукових напрацюваннях різних вчених-кримінологів.

Найбільш значущим у даному питанні є трактування психічного насильства, наведене у Постанові Пленуму Верховного суду України № 2 від 07.02.2003 «Про судову практику в справах про злочини проти життя та здоров'я особи», що психічним насильством слід вважати, наприклад, погрозу завдати фізичної, моральної чи майнової шкоди [10].

Так, більш широкого трактування поняття погрози застосування фізичного насильства набуло у Постанові Пленуму Верховного суду України № 5 від 30.05.2008 «Про судову практику у справах про злочини проти статевої свободи та статевої недоторканості особи», де чітко визначено, що погрозою застосування фізичного насильства як способу подолання чи попередження опору потерпілої особи слід вважати залякування іiі застосуванням такого насильства до неї і (або) до іншої людини, доля якої потерпілій не байдужа (родича, близької особи), яке може полягати у висловлюваннях, жестах, демонструванні зброї або предметів, що можуть бути використані для нанесення тілесних ушкоджень, предметів, що імітують зброю, які потерпіла особа сприймає за справжню зброю, чи інших діях [11].

Разом із тим, звертаючись до ще одного нормативно-правового акта, а саме Постанови Пленуму Верховного суду України № 10 від 06.11.2009 «Про судову практику у справах про злочини проти власності», погроза застосування насильства при розбої полягає в залякуванні негайним застосуванням фізичного насильства, небезпечного для життя і здоров'я потерпілого (погроза вбити, заподіяти тяжке або середньої тяжкості тілесне ушкодження, легке тілесне ушкодження з розладом здоров'я чи незначною втратою працездатності або вчинити певні дії, що у конкретній ситуації можуть спричинити такі наслідки) [12].

Таким чином, виходячи із наведених положень, належить припустити, що погрозою застосування фізичного насильства $є$ дії злочинця, спрямовані на залякування, без фізичного контакту з потерпілим, що мають на меті психологічно вплинути на психоемоційний стан потерпілого з метою досягнення бажаного злочинного результату.

У свою чергу, запобігання таким діям може полягати у декількох аспектах, а саме: попередження та профілактиці вчинення таких дій окремими особами або їх групами, або посилення психологічної підготовленості та моральної стійкості потенційних жертв (спираючись на статистику, наведену вище, найбільш вразливими верствами $є$ особи, які не досягли 14 років, жінки, неповнолітні та особи похилого віку, а також з інвалідністю 1 і 2 груп, але в такому випадку належить бути готовим до наслідків, які полягають у 
майже стовідсотковому застосуванні безпосередньо фізичного насильства, якщо злочинець не досягне бажаного злочинного результату через погрози їх застосування.

Разом $з$ усім вищезазначеним сутність кримінально-спеціального запобігання погрозам застосування полягає в специфічній діяльності окремих органів, до переліку котрих відносять: органи охорони правопорядку (поліція, прокуратура, Служба безпеки України), органи та установи виконання покарання а також інші органи.

Висновки. Таким чином, на підставі проаналізованих наукових підходів до розуміння понять «запобігання злочинності», «кримінально-спеціальне запобігання злочинності», «погроза застосування фізичного насильства» та статистичних даних належить обгрунтувати такі висновки:

- наявний стійкий плюралізм підходів до розуміння поняття профілактики злочинів, але загальноприйнятим вважається, що це система цілеспрямованих заходів 3 протидії, зменшення та можливого подолання злочинності;

- досягнуто висновку, що запобігання злочинності поділяється на різновиди, серед яких є: загальносоціальне запобігання злочинності та кримінально-спеціальне запобігання злочинності;

- не менш глибоким є підхід науковців до дослідження поняття кримінальноспеціального запобігання погроз застосування фізичного насильства, що в свою чергу є такою діяльністю ряду спеціально уповноважених державних органів та громадських організацій, що спрямована на забезпечення безпосереднього правового та кримінологічного впливу на реальні й потенційні злочинні прояви;

- серед напрямків кримінально-спеціального запобігання вчиненню злочинів наявні: кримінологічна профілактика, відвернення злочинів; припинення злочинних проявів, що слугують механізмами, які здійснюють профілактику на різних стадіях вчинення злочинів та в різних умовах;

- дослідивши статистичні дані щодо вчинених злочинів на території України протягом декількох місяців у 2017 році, логічно припустити, що певний відсоток від загальної цифри злочинів відображає злочини, що були вчинені із застосуванням погроз фізичного насильства, що додатково аргументує актуальність вказаної тематики;

- погрозою застосування фізичного насильства $є$ дії злочинця, що спрямовані на залякування, без фізичного контакту з потерпілим дії, що мають на меті психологічно вплинути на психоемоційний стан потерпілого з метою досягнення бажаного злочинного результату;

- аргументовано думку, що, зважаючи на високий рівень злочинності, вказаних форм кримінально-спеціального запобігання вчиненню злочинів не достатньо для формування у громадян свідомої нетерпимості до вчинення таких діянь.

\section{Бібліографічні посилання}

1. Литвак О.М. Державний вплив на злочинність. Кримінологічно-правове дослідження. К.: Юрінком Інтер, 2000. 278 с.

2. Бафия Е. Проблемы криминологии: діалектика криминогенной ситуации. М.: Прогресс, 1978. $149 \mathrm{c}$.

3. Зелінський А.Ф. Кримінологія: курс лекцій. Харків, 1996. 259 с.

4. Загальна характеристика механізму протидії кримінальним правопорушенням (загальносоціальна та спеціальна протидія). URL: https://infopedia.su/1x19fb.html.

5. Поняття і система запобігання злочинності, класифікація запобіжних заходів. URL: http://megapredmet.ru/2-1767.html.

6. Запобігання злочинності (теорія і практика): навч. посіб. / Голіна В.В. Х.: Нац. юрид. акад. України, 2011. 120 с.

7. Співвідношення понять «профілактика», «припинення» та «запобігання». URL: http://textbooks.net.ua/content/view/129/11.

8. Кримінологія: Загальна та Особлива частини: підруч. / І.М. Даньшин, В.В. Голіна, М.Ю. Валуйська та ін.; за заг. ред. В.В. Голіни. 2-ге вид., переробл. і допов. Х.: Право, 2009.

9. Злочинність в Україні: опублікована шокуюча статистика за 2017 рік. URL: http://expres.ua/news/2017/09/05/260751-zlochynnist-ukrayini-opublikovana-shokuyucha-statystyka2017-rik.

10. Постанова Пленуму Верховного Суду України № 2 від 07.02.2003 «Про судову практику в справах про злочини проти життя та здоров'я особи». URL: http://zakon3.rada.gov.ua/laws/show/v0002700-03/print10369697.

11. Постанова Пленуму Верховного Суду України № 5 від 30.05.2008 «Про судову практику у справах про злочини проти статевої свободи та статевої недоторканості особи». URL: http://zakon2.rada.gov.ua/laws/show/v0005700-08. 
12. Постанова Пленуму Верховного Суду України № 10 від 06.11.2009 «Про судову практику у справах про злочини проти власності». URL: http://zakon2.rada.gov.ua/laws/show/v0010700-09.

Надійшла до редакиії 27.03.2018

\section{SUMMARY}

Voloshina Yu.V. Theoretical analysis of special-criminal prevention of threats of use of physical violence. The article analyzes the essence of criminal-special prevention of threats to the use of physical violence, attempts to clarify the essence and study the concepts of «crime prevention», «the threat of using physical violence», «special-criminal prevention», «criminological prevention», «prevention of crime», «Termination of a crime».

The threat of the use of physical violence is the actions of the offender, aimed at intimidation, without physical contact with the victims, with the aim of psychologically affecting the psychoemotional state of the victim in order to achieve the desired criminal result.

The essence of the special-criminal prevention of threats to use is the specific activity of individual bodies, the list of which include: law enforcement agencies (police, prosecutors, the Security Service of Ukraine), penitentiaries and other bodies

Keywords: prevention, physical violence, threat, criminal special prevention, social, violent crime, criminological prevention, prevention of crime, termination of a crime.

Голубош В.В. ${ }^{(0)}$ здобувач

(Національна академія внутрішніх справ)

DOI: $10.31733 / 2078-3566-2018-1-150-155$

\section{ФОРМИ ОБ'ЄКТИВНОЇ СТОРОНИ ЗЛОЧИНІВ ПРОТИ ГРОМАДСЬКОЇ БЕЗПЕКИ, ПРЕДМЕТОМ ЯКИХ С ЗБРОЯ, БОЙОВІ ПРИПАСИ, ВИБУХОВІ РЕЧОВИНИ ТА ВИБУХОВІ ПРИСТРОЇ}

Розкрито особливості форм об'єктивної сторони злочинів проти громадської безпеки, предметом яких є зброя, бойові припаси, вибухові речовини та вибухові пристрої. Здійснено аналіз наукових дискусій щодо їх ознак, сутності та змісту. Вказано на недоліки законодавчого закріплення і розуміння деяких форм об'єктивної сторони зазначених злочинів. Надано пропозиції щодо удосконалення кримінальної відповідальності за вчинення злочинів проти громадської безпеки, предметом яких $є$ зброя, бойові припаси, вибухові речовини та вибухові пристрої.

Ключові слова: громадська безпека, злочини проти громадської безпеки, об'єктивна сторона злочинів проти громадської безпеки, форми об' 'ктивної сторони злочинів проти громадської безпеки.

Постановка проблеми. Як передбачено у ч. 1 ст. 3 Конституції України, безпека людини є однією 3 найвищих соціальних цінностей. Чи не найголовніше місце в Україні займає запобігання та правове забезпечення охорони прав і свобод людини i громадянина, власності, громадського порядку та громадської безпеки, довкілля, конституційного устрою України від злочинних посягань, забезпечення миру і безпеки людства (ч. 1 ст. 1 Кримінального кодексу України (далі - КК). Забезпечення громадської безпеки має надзвичайно важливе значення, оскільки їі ефективність сприяє стабільності суспільства та задоволенню життєвих потреб громадян.

Форми об'єктивної сторони злочинів проти громадської безпеки, предметом яких є зброя, бойові припаси, вибухові речовини та вибухові пристрої, окремо не досліджувалися, незважаючи на наявність в Україні грунтовних теоретичних розробок суміжних питань (громадської безпеки як об'єкта злочину загалом, аналізу окремих складів злочинів проти громадської безпеки, передбачених розділом IX Особливої частини КК). Тому метою даної статті є визначення та характеристика форм об'єктивної сторони злочинів проти громадської безпеки, предметом яких є зброя, бойові припаси, вибухові речовини та вибухові пристрої (ст.ст. 262, 263, 263-1, 264 КК).

(C) Голубош В.В., 2018 